\title{
Corporate Characteristics of Retail Industry among 11 Asian and American Countries
}

\author{
Nurul Zarirah Nizam (Corresponding author) \\ Graduate School of Business Administration \\ Aichi University, 2-10-31Tsutsui Higashi-ku Nagoya, 461-8641, Japan \\ Tel: 81-90-4261-4444Ｅ-mail: zarirah@utem.edu.my \\ $\&$ \\ Faculty of Technology Management \&Technopreneurship \\ University of Technical Malaysia, Melaka, Malaysia

\begin{abstract}
Yasuo Hoshino
Graduate School of Business Administration, Aichi University, Nagoya, Japan

$\&$
\end{abstract}

Institute of Policy and Planning Sciences, University of Tsukuba, Tsukuba, Japan

Received: Oct. 12, 2015

doi:10.5296/jmr.v8i1.8874
Accepted: Nov. 10, $2015 \quad$ Published: January 1, 2016

URL: http://dx.doi.org/10.5296/jmr.v8i1.8874

\begin{abstract}
We use financial ratios of eleven countries such as Malaysia, Japan, USA, Canada, Brazil, Thailand, Indonesia, China, India, Australia, and Cayman Islands in retail industry over the period of 2008 to 2012 to examine corporate characteristics. Hypothesis one is that there are statistically significant differences of financial ratios in retail industry of 11 Asian and American countries. This statement is supported by results of Kruskal Wallis Test. By ANOVA, ROE between Brazil and Thailand, and solvency ratio among Japan, Canada, Thailand and Australia are statistically significantly different from each other.Hypothesis two: Profitability ratios of Japanese Companies are the lowest among 11 countries. This hypothesis is supported partially by ROA except India, both ROE and ROCE except India and Brazil among eleven countries. Not supported by profit margin. Hypothesis 3: Relationship between sales growth ratio and profitability ratios is positive. The positive
\end{abstract}




\section{Macrothink

relationship can be seen in correlations analysis with statistically significant value of sales growth ratio with ROE, ROCE and ROA except profit margin.

Keywords: profitability ratios, Asian countries, American countries, country dummy variables, retail industry 


\section{Introduction}

According to Kalish (2015), retail industry becomes important industry which contributes much for industrial improvement. She also stated that, the most important of retail categories for 2015 which are shaped by the disruptive changes currently impacting the marketplace. The categories are;1) Mobile retailing; rapidly growing business that is expected to approach US $\$ 640$ billion in annual global sales within just a few years. 2) Faster retailing; speed to market, speed to response, and speed to deliver. 3) Experience retailing; shopping and adds entertainment, emotion, deeper engagement, and sometimes even an entire environment.

The key financial ratios for retailers focus on aspects of income, liquidity and profitability performance of their company. Retail managers turn to the gross margin as an indication of the sales dollars remaining after subtracting the costs of purchasing merchandise. It provides managers with an indication of their ability to convert existing inventory into future cash.Generating income and having cash on hand are not the only objectives for smart business owners, so they use profitability ratios to track the growth of the business's net worth. ROA, or return on assets allows retail managers to identify how productively and effectively of the firms using the business' assets to grow, and it enables them to make necessary decisions about under-performing assets. Identifying key financial ratios, however, is just the starting point. Once calculated, smart retail managers compare these ratios to industry standards as benchmarks to gauge their own performance over time. Through comparison and trend analysis, managers can further identify key areas of weaknesses that may need immediate attention. Most importantly same comparisons can also help business owners identify key competitive strengths that may be overlooked.

\section{Literature Review}

\subsection{Theoretical Background}

Report by Pattitoniet al. (2014), economics, management, accounting and financeare the factors to determine the performance of the companies in this recent industry. Most of these studies are based, more or less explicitly, on the structural conduct performance of industrial organization economics. However, while the economic research tradition tends to focus on the industry as the unit of analysis and explains profitability primary as an indirect effect of structural factors, the managerial research is more added oriented towards the firm as a unit of analysis and places greater emphasis on the direct effect of firm's strategic conduct and decisions.

China represents the highest total listed companies in this study. According to Ramanathan and $\mathrm{Yu}$ (2009), during a transforming process from a centrally planned of economy to a market economy, China's retail industry has been experiencing unprecedented development. They have been proven their retail total sales of consumer goods have been growing.

A large body of academic research provides evidence on the usefulness of profitability components as variables for predicting future profitability. Petria etal. (2004) reported there has a positive relationship between firms' profitability and risk, whereas performance of financial ratio has insignificant impact on profitability by analyzing the profitability of 
European banks from 6 countries during the period from 1992 to 1998. They also found that concentration is positively correlated with firms' profitability and that inflation has a strong effect on profitability, while firms' profits are not significantly affected by the real GDP per capita fluctuations on their study on South Eastern European region over the period from 1998 to 2002.

Researchers frequently face difficulties in their attempts to obtain accurate measures of financial performance (Reynolds et al., 2005). The most common problems are the sensitivity of information and its non-availability to the public. In order to tackle the underlying problems of obtaining accurate measures of financial performance, a number of alternative performance measurement models have been applied. Thus, indirect measures of financial indicators to measure firm performance are developed such as by asking the perception of managers on financial performance to compare with their direct competitors. Financial indicators, which have been heavily used in empirical research (Dawson, 2005; Reynolds et al., 2005) represent the success of the economic targets of the organization. In this category one could find mostly indicators of profitability, such ratios as, return on investment, return on equity, return on sales and others. Other variables indicators specify the indirect effect that leads to financial performance. Measures like market share, product or service quality, customer loyalty and customer satisfaction could be treated as other variables indicators (Venkatraman and Ramanujam, 1986).

Most retail studies are conceptual or only based on case studies. There is no studies have empirically shown which strategy is the most successful or in particular whether strategy preferences differ across retail sectors. According to Nizam and Hoshino (2015) study, they focused on retailing industry of three countries (Malaysia, Japan and USA) which emphasize on profitability ratios and safety variables using a few analyses contributed to their hypotheses conclusion. While, Goldman (2001) composes dummy variables of 27 firms from different retail sectors into one index to categories six types of strategies used by retailers in China. In this study, we evaluate our data using regression analysis with dummy variables. It is one of the methods for studying relationship between a quantitative dependent variable and one or more qualitative explanatory variables.

In sum, this study designs to analyze the financial ratios of eleven countries in retail industry by using data five year period of 2008 to 2012. By looking at the comparisons of means value among 11 Asian and American countriesin Table 1, we could include the hypotheses as follows:

Hypothesis 1: There are statistically significant differences of financial ratios in retail industry of 11 Asian and American countries.

Hypothesis 2: Profitability ratios of Japanese Companies are the lowest among 11 countries.

Hypothesis 3: Relationship between sales growth ratio and profitability ratios is positive. 


\section{Methodology}

\subsection{Data set Description}

For our data set description, our sample comprises all private firms from retail industry of 11 Asian and American countries over the periodof2008 to 2012. Data was gathered through annual reports of the listed companies from OSIRIS database and has been analyse by Statistical Package for Social Sciences (SPSS) software version 22. The final sample is composed of312firms. The analysis covers profitability ratios (ROE, ROCE, ROA and profit margin), safety variables (current ratio and solvency ratio), and sales growth ratio.

The selection of the companies based on availability of the data within 2008 to 2012 . Particularly, OSIRIS database has several countries in this retail industry, due to a number of sample is low $80 \%$ of missing data and outlier's data, so we have to eliminate from the sample(for example; Korea which only has 8 companies).

\subsection{Variable Definitions}

Profitability Ratios

1. Return on Shareholders' Funds $=$ Profit Before Tax/Shareholders Funds) $* 100$ (ROE)

2. Return on Capital Employed = Profit Before Tax - Interest Expenses $) /$

(ROCE) (Shareholder Funds + Non-Current Liabilities) * 100

3. Return on Total Assets = Profit Before Tax / Total Assets $) * 100$ (ROA)

4. Profit Margin $=$ Profit Before Tax/Operating Revenue* 100

Safety Ratios

1. Current Ratio $=$ Current Assets $/$ Current Liabilities

2. Solvency Ratio $=($ Shareholders Fund $/$ Total Assets $) * 100$

Sales growth ratio $=($ Current year's sales - Last year's sales $) /$ (Last year's sales) * 100

Source: Profitability and Safety ratios obtained from OSIRIS Database Manual (2013)

\section{Empirical Results}


Table 1. Comparisons of means value among 11 Asian and American countries

\begin{tabular}{|c|c|c|c|c|c|c|c|}
\hline Country & ROE & ROCE & ROA & $\begin{array}{c}\text { Profit } \\
\text { Margin }\end{array}$ & $\begin{array}{c}\text { Current } \\
\text { ratio }\end{array}$ & $\begin{array}{c}\text { Solvency } \\
\text { ratio }\end{array}$ & $\begin{array}{c}\text { Sales } \\
\text { growth } \\
\text { ratio }\end{array}$ \\
\hline Malaysia & 16.68 & 15.45 & 9.96 & 10.75 & 2.59 & 59.74 & 1.64 \\
\hline Japan & 7.91 & 6.15 & 3.51 & 4.30 & 1.15 & 43.49 & 6.73 \\
\hline USA & 18.64 & 11.36 & 7.22 & 6.04 & 1.99 & 46.54 & 3.03 \\
\hline Canada & 20.43 & 13.11 & 7.69 & 6.06 & 1.58 & 42.40 & 3.12 \\
\hline Brazil & 12.45 & 9.62 & 6.32 & 6.40 & 2.39 & 51.88 & 1.96 \\
\hline Thailand & 18.63 & 17.98 & 9.94 & 6.85 & 1.68 & 53.22 & 5.06 \\
\hline Indonesia & 19.87 & 17.86 & 9.37 & 5.62 & 2.23 & 45.57 & 18.74 \\
\hline China & 15.68 & 15.87 & 5.68 & 6.57 & 1.14 & 39.82 & 13.28 \\
\hline India & 9.19 & 9.96 & 3.55 & 3.18 & 4.06 & 50.70 & 9.10 \\
\hline Australia & 20.15 & 17.61 & 7.07 & 6.58 & 1.26 & 39.87 & 4.60 \\
\hline $\begin{array}{c}\text { Cayman } \\
\text { Islands }\end{array}$ & 16.59 & 12.23 & 7.91 & 6.26 & 3.37 & 49.83 & 5.16 \\
\hline
\end{tabular}

Notes: $\quad$ results are based on sample size of Malaysia $=16$, Japan $=64, \mathrm{USA}=53, \mathrm{Canada}=28$, Brazil $=12$,

Cayman Islands $=10$, Thailand $=13$, Indonesia $=13$, China $=63$, India $=17$, Australia $=23$

From Table 1 we can see the comparisons of means value among eleven countries which record Canada has highest mean value of $\mathrm{ROE}=20.43$, Thailand has highest of mean value for ROCE $=17.98$, while Malaysia states the highest of means value for ROA (9.96), profit margin (10.75), and solvency ratio (59.74). Besides, India shows the highest of means value for current ratio (4.06), while Indonesia reports 18.74 for sales growth ratio.

Reported by Warschunet al. (2014) in the AT Kearney's Annual Global Retail Development Index for 2014, Asia's fast-growing economies offer fertile ground for retailers, as expanding populations, rising incomes, and increasing affinity for modern formats help retail sales grow, often quite rapidly. Modern retail is spreading beyond the largest urban to smaller, untapped cities and regions. China: Continued retail growth. Even with less-bullish economic growth, China remains impossible for retailers to ignore. Retail sales in the world's most populous country increased 13\% in 2013 (to $\$ 2.6$ trillion), and consumer confidence rose.

While, Malaysia is a strong and stable market and moves up four spots to 9th, its highest ranking since 2007. Malaysia has a small population (almost 30 million) and economic growth softened in 2013, but its high income per capita of $\$ 10,600$ and young population (nearly half of Malaysians are younger than 25 ages) make it a strong and stable market. According to Kassack et al. (2015), India is a hope for a rebound with growth of economic has lagged the rates of the past decade's boom times, but at 4.7 percent last year, it was an improvement from 2012. Retail is still hindered by high consumer price inflation, currency fluctuations, high current account deficits, government debts, and strict foreign direct investment policies that have long been an impediment to growth. India drops six spots to 20th place, its lowest-ever ranking in the GRDI (Global Retail Development Index). 
Different story goes to Indonesia where expanded their retail sales in January with 10.4\% over the same month of last year, according to Bank Indonesia's Retail Sales Survey (RSS). The expansion was well above the $3.3 \%$ rise observed in December. According to the Bank, January's expansion was driven by strong growth of sales of information and communication equipment as well as of food, beverages and tobacco. Annual average growth in retail sales decreased from $14.4 \%$ in December to $13.4 \%$ in January. According to the survey, retailers expect sales to pick up in February to an $11.4 \%$ annual growth rate. Focus Economics Consensus Forecast participants observe private consumption rising 5.1\% in 2015, which is unchanged from last month's forecast. For 2016, panellists observe growth in private consumption at $5.4 \%$.

In contrast, reported by the U.S. Census Bureau (2015), retail sales in the United States decreased 0.60 percent in February of 2015 over the previous month. Sales in U.S. retail and food stores unexpectedly decreased 0.6 percent from the previous month, following a 0.8 percent drop in January as cold weather kept consumers from shopping malls and car dealers. It was the first time since 2012 that sales had dropped for three consecutive months. In February, retail sales excluding automobiles, gasoline, building materials and food services were unchanged after a 0.1 percent decline in the previous month. Eight of 13 major categories showed declines in February while one remained flat. Car sales dropped 2.5 percent after rising 0.5 percent in January. Receipts at building material and garden equipment stores fell 2.3 percent and sales at restaurants and bars slipped 0.6 percent. There were also declines in furniture and electronic and appliances sales. Sales at clothing stores were flat. In contrast, sales at gasoline stations rose 1.5 percent compared to 9.8 percent drop in January lifted by a recent rise in gasoline prices. Receipts at online stores climbed 2.2 percent and sales at sporting goods and hobby shops increased 2.3 percent.

Table 2. Correlations of all variables of 11 Asian and American countries

\begin{tabular}{|l|l|l|l|l|l|l|l|}
\hline & $(1)$ & $(2)$ & $(3)$ & $(4)$ & $(5)$ & $(6)$ & $(7)$ \\
\hline (1) ROE & 1 & & & & & & \\
\hline (2) ROCE & $.533^{* *}$ & 1 & & & & & \\
\hline (3) ROA & $.477^{* *}$ & $.617^{* *}$ & 1 & & & & \\
\hline (4) Profit margin & $.299^{* *}$ & $.415^{* *}$ & $.627^{* *}$ & 1 & & & \\
\hline (5) Current ratio & -.010 & $-.058^{*}$ & $.082^{* *}$ & $.060^{*}$ & 1 & & \\
\hline (6) Solvency ratio & $-.070^{* *}$ & -.033 & $.295^{* *}$ & $.272^{* *}$ & $.436^{* *}$ & 1 & \\
\hline (7) Sales growth ratio & $.066^{* *}$ & $.101^{* *}$ & $.067^{* *}$ & .034 & -.004 & -.044 & 1 \\
\hline
\end{tabular}

Notes: results are based on sample size of Malaysia $=16$, Japan $=64, \mathrm{USA}=53, \mathrm{Canada}=28$, Brazil $=12$, Cayman Islands $=10$, Thailand $=13$, Indonesia $=13$, China $=63$, India $=17$, Australia $=23$

**. Correlation is significant at the 0.01 level (2-tailed).

*. Correlation is significant at the 0.05 level (2-tailed).

As we can see from Table 2illustrates significance values are less than 0.01 and 0.05 which tell us that the probability of getting a correlation coefficient this big in a sample of 312 of the total listed companies among 11 Asian and American countries. Referring the significance 


\section{Macrothink}

Journal of Management Research ISSN 1941-899X 2016, Vol. 8, No. 1

value, which below the standard criterion of .05 , indicating a 'statistically significant' relationship. Correlation refers to a technique used to measure the relationship between two or more variables. Thus we could conclude that there has a positive correlation among profitability ratios, safety ratios and sales growth ratio. The correlations are ROCE and current ratio with $r=-.058$, ROA and current ratio with $r=.082$, profit margin and current ratio $(r=.060)$, ROE and solvency ratio $r=-.070$, ROA and solvency ratio $(r=.295)$, profit margin and solvency ratio $(r=.272)$.This means, by looking at the correlation of ROCE and solvency ratio as an example (evaluates how efficiently a company's available capital is utilized)(measures profitability and financial efficiency), a higher ROCE indicates more efficient use of capital. ROCE should be higher than the company's capital cost, otherwise it indicates that the company is not employing its capital effectively and not generating shareholder value.

While for sales growth ratio, we could conclude that there is statistically significance difference between sales growth ratio and profitability ratios. The correlations are sales growth ratio and ROE (.066), sales growth ratio and ROCE (.101), and sales growth ratio and ROA (.067).

Table 3. Tests of normality among 11 Asian and American countries of profitability ratios, safety ratios and sales growth ratio

\begin{tabular}{|c|c|c|c|c|c|c|c|}
\hline \multirow{13}{*}{ ROE } & \multirow[t]{2}{*}{ Country } & \multicolumn{3}{|c|}{ Kolmogorov-Smirnov ${ }^{\mathrm{a}}$} & \multicolumn{3}{|c|}{ Shapiro-Wilk } \\
\hline & & Statistic & $\mathrm{df}$ & Sig. & Statistic & df & Sig. \\
\hline & Malaysia & .107 & 80 & .025 & .962 & 80 & .017 \\
\hline & Japan & .110 & 320 & .000 & .939 & 320 & .000 \\
\hline & Canada & .338 & 140 & .000 & .182 & 140 & .000 \\
\hline & Brazil & .091 & 60 & $.200^{*}$ & .941 & 60 & .006 \\
\hline & Thailand & .056 & 65 & $.200^{*}$ & .985 & 65 & .642 \\
\hline & Indonesia & .130 & 65 & .008 & .924 & 65 & .001 \\
\hline & China & .154 & 325 & .000 & .774 & 325 & .000 \\
\hline & India & .138 & 85 & .000 & .925 & 85 & .000 \\
\hline & Australia & .219 & 115 & .000 & .727 & 115 & .000 \\
\hline & USA & .158 & 261 & .000 & .888 & 261 & .000 \\
\hline & $\begin{array}{l}\text { Cayman } \\
\text { Islands }\end{array}$ & .235 & 50 & .000 & .656 & 50 & .000 \\
\hline & Malaysia & .088 & 80 & .193 & .967 & 80 & .036 \\
\hline & Japan & .125 & 320 & .000 & .892 & 320 & .000 \\
\hline & Canada & .142 & 140 & .000 & .896 & 140 & .000 \\
\hline & Brazil & .110 & 60 & .070 & .949 & 60 & .014 \\
\hline ROCE & Thailand & .043 & 65 & $.200^{*}$ & .993 & 65 & .979 \\
\hline & Indonesia & .127 & 65 & .011 & .833 & 65 & .000 \\
\hline & China & .174 & 325 & .000 & .628 & 325 & .000 \\
\hline & India & .104 & 85 & .025 & .935 & 85 & .000 \\
\hline & Australia & .212 & 115 & .000 & .529 & 115 & .000 \\
\hline
\end{tabular}




\begin{tabular}{|c|c|c|c|c|c|c|c|}
\hline & USA & .154 & 261 & .000 & .822 & 261 & .000 \\
\hline & $\begin{array}{c}\text { Cayman } \\
\text { Islands }\end{array}$ & .138 & 50 & .019 & .915 & 50 & .002 \\
\hline \multirow{11}{*}{ ROA } & Malaysia & .141 & 80 & .000 & .916 & 80 & .000 \\
\hline & Japan & .129 & 320 & .000 & .847 & 320 & .000 \\
\hline & Canada & .102 & 140 & .001 & .941 & 140 & .000 \\
\hline & Brazil & .118 & 60 & .036 & .928 & 60 & .002 \\
\hline & Thailand & .089 & 65 & $.200^{*}$ & .982 & 65 & .443 \\
\hline & Indonesia & .120 & 65 & .022 & .872 & 65 & .000 \\
\hline & China & .083 & 325 & .000 & .959 & 325 & .000 \\
\hline & India & .142 & 85 & .000 & .912 & 85 & .000 \\
\hline & Australia & .128 & 115 & .000 & .866 & 115 & .000 \\
\hline & USA & .109 & 261 & .000 & .923 & 261 & .000 \\
\hline & $\begin{array}{c}\text { Cayman } \\
\text { Islands }\end{array}$ & .110 & 50 & .178 & .928 & 50 & .005 \\
\hline \multirow{11}{*}{ Profit Margin } & Malaysia & .103 & 80 & .037 & .963 & 80 & .021 \\
\hline & Japan & .147 & 320 & .000 & .840 & 320 & .000 \\
\hline & Canada & .073 & 140 & .067 & .967 & 140 & .002 \\
\hline & Brazil & .213 & 60 & .000 & .845 & 60 & .000 \\
\hline & Thailand & .114 & 65 & .037 & .974 & 65 & .190 \\
\hline & Indonesia & .113 & 65 & .039 & .959 & 65 & .030 \\
\hline & China & .189 & 325 & .000 & .704 & 325 & .000 \\
\hline & India & .171 & 85 & .000 & .878 & 85 & .000 \\
\hline & Australia & .193 & 115 & .000 & .812 & 115 & .000 \\
\hline & USA & .081 & 261 & .000 & .977 & 261 & .000 \\
\hline & $\begin{array}{l}\text { Cayman } \\
\text { Islands }\end{array}$ & .133 & 50 & .026 & .858 & 50 & .000 \\
\hline \multirow{11}{*}{ Current ratio } & Malaysia & .187 & 80 & .000 & .820 & 80 & .000 \\
\hline & Japan & .151 & 320 & .000 & .841 & 320 & .000 \\
\hline & Canada & .087 & 140 & .011 & .949 & 140 & .000 \\
\hline & Brazil & .093 & 60 & $.200^{*}$ & .940 & 60 & .005 \\
\hline & Thailand & .224 & 65 & .000 & .850 & 65 & .000 \\
\hline & Indonesia & .323 & 65 & .000 & .632 & 65 & .000 \\
\hline & China & .147 & 325 & .000 & .704 & 325 & .000 \\
\hline & India & .295 & 85 & .000 & .652 & 85 & .000 \\
\hline & Australia & .162 & 115 & .000 & .895 & 115 & .000 \\
\hline & USA & .154 & 261 & .000 & .795 & 261 & .000 \\
\hline & $\begin{array}{l}\text { Cayman } \\
\text { Islands }\end{array}$ & .278 & 50 & .000 & .675 & 50 & .000 \\
\hline \multirow{2}{*}{ Solvency ratio } & Malaysia & .093 & 80 & .082 & .967 & 80 & .037 \\
\hline & Japan & .038 & 320 & $.200^{*}$ & .990 & 320 & .034 \\
\hline
\end{tabular}




\begin{tabular}{|c|c|c|c|c|c|c|c|}
\hline & Canada & .056 & 140 & $.200^{*}$ & .988 & 140 & .247 \\
\hline & Brazil & .149 & 60 & .002 & .921 & 60 & .001 \\
\hline & Thailand & .094 & 65 & $.200^{*}$ & .970 & 65 & .116 \\
\hline & Indonesia & .173 & 65 & .000 & .924 & 65 & .001 \\
\hline & China & .062 & 325 & .004 & .978 & 325 & .000 \\
\hline & India & .099 & 85 & .040 & .945 & 85 & .001 \\
\hline & Australia & .058 & 115 & $.200^{*}$ & .992 & 115 & .742 \\
\hline & USA & .102 & 261 & .000 & .945 & 261 & .000 \\
\hline & $\begin{array}{l}\text { Cayman } \\
\text { Islands }\end{array}$ & .150 & 50 & .006 & .924 & 50 & .003 \\
\hline \multirow{11}{*}{$\begin{array}{l}\text { Sales growth } \\
\text { ratio }\end{array}$} & Malaysia & .173 & 80 & .000 & .834 & 80 & .000 \\
\hline & Japan & .219 & 320 & .000 & .645 & 320 & .000 \\
\hline & Canada & .137 & 140 & .000 & .896 & 140 & .000 \\
\hline & Brazil & .151 & 60 & .002 & .960 & 60 & .048 \\
\hline & Thailand & .430 & 65 & .000 & .289 & 65 & .000 \\
\hline & Indonesia & .303 & 65 & .000 & .603 & 65 & .000 \\
\hline & China & .237 & 325 & .000 & .517 & 325 & .000 \\
\hline & India & .256 & 85 & .000 & .592 & 85 & .000 \\
\hline & Australia & .168 & 115 & .000 & .778 & 115 & .000 \\
\hline & USA & .116 & 261 & .000 & .913 & 261 & .000 \\
\hline & $\begin{array}{l}\text { Cayman } \\
\text { Islands }\end{array}$ & .163 & 50 & .002 & .910 & 50 & .001 \\
\hline
\end{tabular}

*. This is a lower bound of the true significance.

a. Lilliefors Significance Correction

Table 4. Comparisons of profitability ratios, safety ratios and sales growth ratio among 11 Asian and American countries using Kruskal-Wallis Test

Test Statistics ${ }^{\mathrm{a}, \mathrm{b}}$

\begin{tabular}{|l|c|c|c|c|c|c|c|}
\hline & ROE & ROCE & ROA & $\begin{array}{c}\text { Profit } \\
\text { Margin }\end{array}$ & $\begin{array}{c}\text { Current } \\
\text { ratio }\end{array}$ & $\begin{array}{c}\text { Solvency } \\
\text { ratio }\end{array}$ & $\begin{array}{c}\text { Sales growth } \\
\text { rate }\end{array}$ \\
\hline Chi-Square & 262.099 & 378.652 & 260.217 & 121.130 & 455.765 & 126.969 & 189.622 \\
\hline df & 10 & 10 & 10 & 10 & 10 & 10 & 10 \\
\hline $\begin{array}{l}\text { Asymp. } \\
\text { Sig. }\end{array}$ & .000 & .000 & .000 & .000 & .000 & .000 & .000 \\
\hline
\end{tabular}
a. Kruskal Wallis Test
b. Grouping Variable: country 
Table 5. Pairwise comparisons results for the Tukey post hoc test

\begin{tabular}{|c|c|c|c|c|c|}
\hline Country & Variables & Mean Square & df & F & Sig. \\
\hline $\begin{array}{c}\text { Brazil } \\
\text { Thailand }\end{array}$ & ROE & 3806.521 & & 7.306 & .000 \\
\hline $\begin{array}{c}\text { Japan } \\
\text { Canada } \\
\text { Thailand } \\
\text { Australia }\end{array}$ & Solvency ratio & 4259.408 & & 10 & \\
\cline { 5 - 6 }
\end{tabular}

The normality assumption also needs to be considering for validation of data present in the literature as it shows whether correct statistical tests have been used. From Table 3, we can see the symbol of asterisk, a value of .200 includes of ROE (Brazil and Thailand), ROCE (Thailand), ROA (Thailand), current ratio (Brazil), solvency ratio (Canada, Thailand and Australia), current ratio (Brazil), and solvency ratio (Japan, Canada, Thailand and Australia). The purpose of this report is to overview the procedures for checking normality in statistical analysis using SPSS.

Table 4 shows a Kruskal-Wallis test of all variables (profitability ratios, safety ratios and sales growth ratio) among those eleven countries, where there is a statistically significant difference with the value of $p=0.000$. It is important to realize that the Kruskal-Wallis test is a general test statistic and cannot tell us which specific groups of the independent variable are statistically significantly different from each other. It only tells us that at least two groups were different.

Since we have seven variables in this study, determining which of these groups differ from each other is important. Then, we have to apply a post hoc test. The pair wise comparisons function is to determine which group differed from each other. The variables in this analysis have been taken by referring the normality test from Table 3 (looking at the asterisk (*) which indicates a lower bound of the true significant). While the results of Tukey post-hoc test show that for ROE (Brazil and Thailand) with the means value of 12.45 and 18.63 respectively, and solvency ratio (Japan, Canada, Thailand and Australia) with means value of $43.49,42.40,53.22$ and 39.87 of each are statistically significantly different from each other as showing in Table 5.

\subsection{Dummy variables in Regression Analysis}

According to Modupe (2012), to represent subgroups of the sample in any study, the best way to run a regression analysis is using a dummy variable. In research design, a dummy variable is often used to distinguish different treatment groups. In the simplest case, there is a 0,1 dummy variable where a subject is given a value of 0 if they are in the reference group or a 1 if they are in the group of interest. Dummy variables are useful because they enable us to use a single regression equation to represent multiple groups. This means that we do not need to write out separate equation models for each subgroup. The dummy variables act like 'switches' that turn various parameters on and off in an equation. 
In this study, we chose the stepwise method where is a combination method of forward entry and backward removal. Predictors are entered in the regression model one at a time based on how much they will improve model fit. A new model will be added each time, the predictors already in the model are evaluated and may be removed if they are no longer significantly improve the fit of the model.

Table 6. Regression results including country dummy variables (Japan as reference country).

\begin{tabular}{|c|c|c|c|c|}
\hline $\begin{array}{l}\text { Dependent } \\
\text { variable }\end{array}$ & Independent variable & $\begin{array}{c}\text { Standardized Coefficients } \\
\text { Beta }\end{array}$ & $t$ & Sig. \\
\hline \multirow[t]{10}{*}{ ROE } & Solvency ratio & -.065 & -2.514 & .012 \\
\hline & Sales growth ratio & .068 & 2.691 & .007 \\
\hline & Malaysia & .087 & 3.281 & .001 \\
\hline & USA & .154 & 5.524 & .000 \\
\hline & Canada & .173 & 6.440 & .000 \\
\hline & Thailand & .080 & 3.059 & .002 \\
\hline & Indonesia & .087 & 3.366 & .001 \\
\hline & China & .099 & 3.460 & .001 \\
\hline & Australia & .120 & 4.513 & .000 \\
\hline & Cayman Islands & .050 & 1.969 & .049 \\
\hline \multirow[t]{9}{*}{ ROCE } & Sales growth ratio & .080 & 3.271 & .001 \\
\hline & Malaysia & .140 & 5.534 & .000 \\
\hline & USA & .109 & 3.992 & .000 \\
\hline & Canada & .127 & 4.868 & .000 \\
\hline & Thailand & .155 & 7.027 & .000 \\
\hline & Indonesia & .156 & 6.184 & .000 \\
\hline & China & .258 & 9.295 & .000 \\
\hline & Australia & .209 & 8.092 & .000 \\
\hline & Cayman Islands & .052 & 2.093 & .037 \\
\hline \multirow[t]{12}{*}{$\mathrm{ROA}$} & Current ratio & -.068 & -2.573 & .010 \\
\hline & Solvency ratio & .310 & 11.741 & .000 \\
\hline & Sales growth ratio & .076 & 3.213 & .001 \\
\hline & Malaysia & .167 & 6.724 & .000 \\
\hline & USA & .197 & 7.363 & .000 \\
\hline & Brazil & .050 & 2.063 & .039 \\
\hline & Canada & .192 & 7.549 & .000 \\
\hline & Thailand & .157 & 6.392 & .000 \\
\hline & Indonesia & .173 & 7.121 & .000 \\
\hline & China & .147 & 5.306 & .000 \\
\hline & Australia & .159 & 6.308 & .000 \\
\hline & Cayman Islands & .096 & 3.963 & .000 \\
\hline
\end{tabular}




\begin{tabular}{|c|c|c|c|c|}
\hline Profit Margin & Solvency ratio & .279 & 11.282 & .000 \\
\cline { 2 - 5 } & Sales growth ratio & .057 & 2.381 & .017 \\
\cline { 2 - 5 } & Malaysia & .124 & 5.058 & .000 \\
\cline { 2 - 5 } & India & -.103 & -4.216 & .000 \\
\cline { 2 - 5 } & China & .097 & 3.919 & .000 \\
\cline { 2 - 5 } & Australia & .068 & 2.786 & .005 \\
\hline
\end{tabular}

Particularly, we put profitability ratios as dependent variables, while safety ratio, sales growth ratio and country dummy variables as independent variables. We choose Japan as our reference country due to the lowest profitability ratios among others; choosing the country with lowest profitability ratios will give positive coefficients for the other variables, which might be easier to explain in the results. The table only show the significant value of all variables. Thus, it is telling these findings imply that there are different financial ratios in retail industry of 11 Asian and American countries. From Table 6, dummy variables of nine countries have positive effect on ROA, namely those nine countries have higher ROA comparing with Japan except India. As far as ROE and ROCE are concerned, dummy variables of eight countries have positive effects on those ratios, that is, except Brazil and India, those ratios are higher comparing with Japan. So far, we could support hypothesis two partially. However, profit margin does not support this hypothesis.

\section{Test of Hypotheses and Discussion}

Hypothesis 1; There are statistically significant differences of financial ratios in retail industry of 11 Asian and American countries. This statement is supported by tests of normality, Kruskal-Wallis test and Tukey post hoc test as shown in Table 3, 4 and 5 respectively. The results report that ROE (Brazil and Thailand) with the means value of $12.45 \%$ and $18.63 \%$ respectively, and solvency ratio (Japan, Canada, Thailand and Australia) with means value of $43.49 \%, 42.40 \%, 53.22 \%$ and $39.87 \%$ respectively, which are statistically significantly different from each other as shown in Table 5.

Hypothesis 2;Profitability ratios of Japanese Companies are the lowest among 11 countries. This hypothesis is supported partially by ROA except India, and ROE and ROCE except India and Brazil among eleven countries. Not supported by profit margin.

Hypothesis 3; Relationship between sales growth ratio and profitability ratios is positive. By referring to Table 2, the positive relationship can be seen in correlations analysis with statistically significance value of sales growth ratio with ROE, ROCE and ROA except for profit margin. According to Yuchenget al (2015) in their study of China's mid-range and high-end liquor industry, the higher market share with lower ratio of sales is not significant and it deviates from the normal track of companies' growth. Therefore, if the industry wants to maintain their availability in the marketplace, they should increase ratio of sales with significant market share or enlarge market share supported by sustained high ratio of sales. This is a powerful success discipline to sustain long in the industry itself. 


\section{Conclusion and Future Research}

Retail industry is becoming more international and there is overall a new need for firms to expand abroad to generate new growth. Firms in each country must grapple with fundamental branding and technology decisions when they pursue such channels. These decisions have important, potentially long lasting effects on the fates of their company, but few researchers have examined the patterns and consequences of these decisions as well.

As discussed, the result of this study show that the differences of financial ratios in retail industry of 11 Asian and American countries. Reported by Kawazu (2013), the total GDP for the ASEAN (Association of Southeast Asian Nations) countries has grown to the same level as the GDP of each of three significant emerging economies like Brazil, Russia and India. Her study also discussed that in the world's population of 7 billion, 60 per cent (4.2 billion) live in Asia. United Nations predicts that population of Asia will continue to grow steadily with the majority of growth occurring in China and India. This means, there is no prospect of any significant future population growth in developed countries like North America and Europe. Definitely, Asia will be the most importance to focus for the world's customer markets. This statement show the reason of the differences occurred and population becoming the greatest issues affecting the retail industry of each countries.

While profitability ratios of Japanese Companies are the lowest among 11 countries revealed in the results perhaps due to Japan's domestic market is lower than global standards. According to Mizuho Corporate Bank (2012), there are several reasons contribute to production activities declining. The reasons are due to the Great East Japan Earthquake and tsunami, the massive flooding in Thailand, followed by a global decline in demand (caused mainly by the European financial crisis) and monetary policy tightening in China. But, the greatest risk factor for the Japanese economy in 2012 is the overseas economic environment which highlights the European financial crisis spilling over into the emerging countries, mainly Asia through the reduction of the assets.

On the other hand, referring to Ito (2014) in his review of ROE of Japanese Companies, stated a few reasons why ROE of Japanese companies is low than other countries. One of the reasons is a company's earning power and competitiveness is constrained by excessive price competition due to insufficient differentiation, product positioning, business portfolio optimization, innovation, and responses to changes in business environments. Ito also mentioned that excessive cash and deposits on the balance sheet have also contributed to low ROE. A high ratio of cash, deposits and marketable securities to total assets will result in lowering ROA given that the yield of government bonds is below 1 per cent. Although some USA companies have large cash and deposits, it was noted that the majority of such companies exhibit above average ROE due to very high profit margins. Other reasons mentioned include the mindset of management towards ROE and governance model centred on bank financing.

Meanwhile, sales growth ratio itself tells us how fast a company is growing. Indirectly, the changes in profitability ratios affected the growth of the company. From this study we can see the positive correlations of sales growth ratio with ROE, ROCE, and ROA except for profit 
margin. Besides that, retail revenue figures in this study reflect only the retail portion of the company's consolidated profitability ratios, safety variables, and sales growth ratio. As a result, the reports figures excluded non-retail operation of the listed companies. This study includes foodservice sales, sales of services related to the company's retail activities, such as alterations, repair, maintenance, installation and membership fees. It should also be noted that the financial information used for each company in a given year is accurate of the data the financial report was originally issued.

Finally, this paper opens up a fruitful avenue for future empirical research. It would be interesting to explore decisions from the top management of each company in retail industry instead of depending on performance of profitability ratios (availability database). The real process and situations could be acknowledged on giving an idea for some other discussions on performance decisions. In addition, although the statistics literature explicitly argues the use of standardized dummy regression analysis as measures of effect, there appears to be lack of awareness about this issue in performance of financial in future particularly for overall corporate variable factors that apply the technique. So, for future research might use and added a crucial variables which really effect the performance of financial in retail industry and more countries to be explored.

\section{Acknowledgement}

This study supported by JSPS KAKENHI Grant Number 24530500, Universiti Teknikal Malaysia Melaka (UTeM), and Ministry of Higher Education (MOHE), Malaysia. All errors and omissions are the responsibility of the authors.

\section{References}

Anitha, R., \& Nowfal. (2014). Impact of Liquidity Management on Profitability: A Case Study of Malappuram Co-Operative Spinning Mills Limited, Kerala. Asian Journal of Management, 5(3), 353-358.

Dawson, J. (2005). Output Considerations in Retail Productivity. International Review of Retail, Distribution and Consumer Research, 14(3), 337-349. http://dx.doi.org/10.1080/09593960500119432

Modupe, O.D. (2012). A Dummy Variable Regression on Students' Academic Performance. Transnational Journal of Science and Technology, 2(6), 47-54.

Nizam, N.Z., \& Hoshino, Y., (2015). Corporate Characteristics of Retailing Companies among Malaysia, Japan and USA. International Journal of Business and Management, 10(6), 40 - 52. http://dx.doi.org/10.5539/ijbm.v10n6p40

Petria, N., Capraru, B., \& Ihnatov, I. (2015). Determinants of Banks' Profitability: Evidence from EU 27 Banking Systems. Procedia Economics and Finance, 20, 518-524. http://dx.doi.org/10.1016/S2212-5671(15)00104-5 
Ramanathan, R., \& Yu, W. (2009). An Assessment of Operational Efficiency of Retail Firms in China. Journal of Retailing and Consumer Services, 16(2), 109-122. http://dx.doi.org/10.1016/j.jretconser.2008.11.009

Reynolds, J., Howard, E., Dragun, D., Rosewell, B., Ormerod, P. (2005). Assessing the Productivity of the UK Retail Sector. International Review of Retail, Distribution and Consumer Research, 14(3), 337-349. http://dx.doi.org/10.1080/09593960500119416

Roberts, P.W., \& Dowling, G.R. (2002). Corporate Reputation and Sustained Superior Financial Performance. Strategic Management Journal, 23, 1077-1093. http://dx.doi.org/10.1002/smj.274

Ramdhani, A., Turipanam, D., Syakur, A.A. (2010). The Importance Of Retail Service Quality And Store Image In Creating Customer Loyalty. Global Management Conference, 161-165.

Sam, M. F. M., \& Hoshino, Y. (2013).Performance of ICT Industry in Six Asian Countries. International Journal of Business Administration, 4(6), 96-119.

Srivastava, R.K. (2008). Changing retail scene in India. International Journal of Retail \& Distribution Management, 36(9), 714 - 721. http://dx.doi.org/10.1108/09590550810890957

Venkatraman, N., \& Ramanujam, V. (1986). Measurement of Business Performance in Strategy Research: A Comparison of Approaches. Academy of Management Review, 11(4), 801-814.

Yucheng, H., Wenna, D., Qian, Z., Guang, Y., \& Fangqiang, L. (2015). Empirical Study on the Relationship between Market Share, Advertising Density and Ratio of Sales. Journal of Food Technology Research, 2(1), 11-20.

Pattitoni, P., Petracci, B., \& Spisni, M. (2014). Determinants of Profitability in the EU-15 $\begin{array}{llll}\text { area. } & \text { Applied } & \text { Financial } & \text { Economics, }\end{array}$ http://dx.doi.org/10.1080/09603107.2014.904488

Ito, K. (2014). Final Report: Review of Competitiveness and Incentives for Sustainable Growth - Building Favorable Relationships between Companies and Investors. Ministry of Economy, Trade and Industry of Japan (METI). Retrieved from http://www.meti.go.jp/english/press/2014/pdf/0806_04b.pdf.

Kalish, I. (2015). Deloitte: Global Powers of Retailing 2015 Embracing innovation. Retrieved from

http://www2.deloitte.com/me/en/pages/consumer-business/articles/global-powers-of-retailing .html.

Kassack, J., Torres, J., Shabat, H.B., \& Moriarty, M. (2015). Global Retail Expansion: An Unstoppable Force The 2015 Global Retail Development Index ${ }^{\mathrm{TM}}$. Retrived from https://www.atkearney.com/consumer-products-retail/global-retail-development-index. 
Kawazu, N. (2013). Consumer Trends and Expansion of Retail Markets in Growing ASEAN Economies.Nomura Research Institute Papers.Retrieved from https://www.nri.com/global/opinion/papers/2013/pdf/np2013182.pdf.

Mizuho Corporate Bank. (2012). Japan Industry Outlook/38: Comprehensive Industry. Retrieved from http://www.mizuhobank.com/fin_info/industry/pdf/1038_01.pdf.

Warschun, M., Olsen, G., \& Hillier, D. (2014). AT Kearney's Annual Global Retail Development Index for 2014: Full Steam Ahead for Global Retailers. Retrived from http://www.atkearney.com/consumer-products-retail/global-retail-development-index/full-rep ort.

U.S. Census Bureau. (2015). Trading Economics: United States Retail Sales of .Retrieved from http://www.tradingeconomics.com/united-states/retail-sales.

Boslaugh, S. (2013).Statistics in a Nutshell (2nd Edition). O'Reilly Media Inc.

Field, A. (2013). Discovering Statistics Using IBM SPSS Statistics (4th Edition). SAGE Publications Inc.

Gitman, L.J., Juchau, R., \& Flanagan, J. (2010). Principles of Managerial Finance (6th Edition). Pearson.

Ross, S.A., Bianchi, R., Drew, M., Christensen, M.J., Westerfield, R.W., \& Jordan, B.D. (2014). Fundamentals of Corporate Finance (6th Australian Edition). McGraw Hill Inc.

Chugan, P.K. \& Rawani, M. (2012). Accelerating Human Resource Performance for Sustainable Growth: The Indian Textiles and Clothing Industry. Global Recession to Global Recovery: Enhancing Enterprise Competitiveness Through Human Capital And Operations Management, 141-157.

Biao, N., Feng, Z., \& Jiafeng, Y.U. (2010). The Impact of the Financial Crisis on Consumer Behavior and the Implications of Retail Revolution. Retrieved from www.seiofbluemountain.com/upload/product/.../2010shcyx06a12.pdf.

Kaplan, R.S., \& Norton, D.P. (1996). Using the Balance Scorecard as a Strategic Management System. Harvard Business Review, 74(1), 75-85.

Bureau van Dijk Electronic Publishing. (2013). OSIRIS Database Manual, Bureau van Dijk Electronic Publishing, 44-53.

\section{Appendix - Listed Companies}

Malaysia

\begin{tabular}{|l|l|l|}
\hline 1. PARKSON HOLDINGS BERHAD & 2. MBM RESOURCES BHD & $\begin{array}{l}\text { 3. THE STORE CORPORATION } \\
\text { BERHAD }\end{array}$ \\
\hline 4. ATLAN HOLDINGS BHD & 5. PADINI HOLDINGS BERHAD & $\begin{array}{l}\text { 6. CYCLE \& CARRIAGE BINTANG } \\
\text { BERHAD }\end{array}$ \\
\hline 7. TOMEI CONSOLIDATED & 8. BONIA CORPORATION BHD & 9. SUIWAH CORPORATION BHD \\
\hline
\end{tabular}




\begin{tabular}{|l|l|l|}
\hline BERHAD & & \\
\hline 10. HAI-O ENTERPRISE BERHAD & 11. FIAMMA HOLDINGS BHD & 12. KAMDAR GROUP (M) BERHAD \\
\hline 13. CNI HOLDINGS BERHAD & 14. MARCO HOLDINGS BERHAD & $\begin{array}{c}\text { 15. TEO GUAN LEE } \\
\text { CORPORATION BHD }\end{array}$ \\
\hline 16. FCW HOLDINGS BHD & \multicolumn{2}{|l}{} \\
\hline
\end{tabular}

\begin{tabular}{|c|c|c|}
\hline 1. SEVEN \& I HOLDINGS CO., LTD. & 2. KIRIN HOLDINGS CO., LTD. & 3. JAPAN TOBACCO INC \\
\hline 4. ASAHI GROUP HOLDINGS LTD. & 5. YAMADA DENKI CO LTD & 6. J. FRONT RETAILING CO. LTD. \\
\hline 7. FAST RETAILING CO LTD & 8. YAMAZAKI BAKING CO LTD & 9. NIPPON MEAT PACKERS INC \\
\hline $\begin{array}{l}\text { 10. TAKASHIMAYA COMPANY } \\
\text { LIMITED }\end{array}$ & 11. KATO SANGYO CO LTD & 12. PALTAC CORPORATION \\
\hline 13. BIC CAMERA INC. & 14. SHISEIDO COMPANY LIMITED & 15. K'S HOLDINGS CORP. \\
\hline 16. ITOCHU-SHOKUHIN CO LTD & $\begin{array}{l}\text { 17. MORINAGA } \\
\text { INDUSTRY CO LTD }\end{array}$ & 18. KEWPIE CORPORATION \\
\hline 19. DON QUIJOTE CO. LTD. & 20. IZUMI CO LTD & 21. SAPPORO HOLDINGS LIMITED \\
\hline 22. H2O RETAILING CORP. & 23. SHIMAMURA CO LTD & 24. LAWSON INC \\
\hline 25. UNICHARM CORPORATION & 26. NICHIREI CORPORATION & $\begin{array}{l}27 . \quad \text { MATSUMOTOKIYOSHI } \\
\text { HOLDINGS CO LTD }\end{array}$ \\
\hline 28. NISSHIN SEIFUN GROUP INC & 29. DCM HOLDINGS CO., LTD. & 30. ARCS CO., LTD. \\
\hline 31. VALOR CO LTD & 32. HEIWADO CO LTD & 33. ITO EN LTD \\
\hline $\begin{array}{l}\text { 34. NISSIN FOOD HOLDINGS CO., } \\
\text { LTD. }\end{array}$ & 35. AT-GROUP CO., LTD. & 36. JOSHIN DENKI CO LTD \\
\hline 37. LION CORPORATION & 38. NITORI HOLDINGS CO., LTD. & 39. SUGI HOLDINGS CO., LTD. \\
\hline 40. TOYO SUISAN KAISHA LTD & 41. FAMILY MART CO LTD & 42. THE MARUETSU INC \\
\hline 43. TSURUHA HOLDINGS INC & 44. KOMERI CO LTD & 45. YAKULT HONSHA CO LTD \\
\hline 46. YAMAE HISANO CO., LTD. & 47. NISSHIN OILLIO GROUP LTD. & $\begin{array}{l}\text { 48. COSMOS PHARMACEUTICAL } \\
\text { CORPORATION }\end{array}$ \\
\hline 49. OKUWA CO LTD & 50. KIKKOMAN CORPORATION & 51. KOHNAN SHOJI CO LTD \\
\hline
\end{tabular}




\begin{tabular}{|c|c|c|}
\hline 52. PRIMA MEAT PACKERS LTD & 53. PARCO CO LTD & 54. NIPPON FLOUR MILLS CO LTD \\
\hline $\begin{array}{l}\text { 55. MAXVALU NISHINIHON CO., } \\
\text { LTD. }\end{array}$ & $\begin{array}{l}\text { 56. } \\
\text { CORPORATION }\end{array}$ & 57. AEON KYUSHU CO., LTD. \\
\hline 58. STARZEN COMPANY LIMITED & 59. YAOKO CO LTD & 60. KASUMI CO LTD \\
\hline 61. CAWACHI LIMITED & 62. SHOWA SANGYO CO LTD & 63. NAFCO CO LTD. \\
\hline 64. AUTOBACS SEVEN CO LTD & & \\
\hline
\end{tabular}

USA

\begin{tabular}{|c|c|c|c|c|c|}
\hline 1. & $\begin{array}{l}\text { SEARS HOLDINGS } \\
\text { CORPORATION }\end{array}$ & 2. & TUESDAY MORNING CORP & 3. & $\begin{array}{l}\text { VOXX INTERNATIONAL } \\
\text { CORPORATION }\end{array}$ \\
\hline 4. & ZALE CORP & 5. & COLDWATER CREEK INC & 6. & VALUEVISION MEDIA, INC. \\
\hline 7. & $\begin{array}{l}\text { PEP BOYS MANNY MOE \& } \\
\text { JACK }\end{array}$ & 8. & $\begin{array}{l}\text { HAVERTY FURNITURE } \\
\text { COMPANIES INC }\end{array}$ & 9. & MARINEMAX INC \\
\hline 10. & $\begin{array}{l}\text { CHILDREN'S PLACE RETAIL } \\
\text { STORES, INC. (THE) }\end{array}$ & 11. & CITI TRENDS, INC. & 12. & $\begin{array}{l}\text { DESTINATION MATERNITY } \\
\text { CORPORATION }\end{array}$ \\
\hline 13. & PIER 1 IMPORTS INC & & $\begin{array}{l}\text { PERFUMANIA HOLDINGS, } \\
\text { INC. }\end{array}$ & 15. & CACHE INC \\
\hline 16. & STAGE STORES INC & 17. & AUTONATION INC & 18. & OFFICE DEPOT INC \\
\hline 19. & NEW YORK \& COMPANY, INC. & 20. & SALLUSTRO Y CIA SRL & 21. & GARCIA REGUERA S.A. \\
\hline 22. & VITAMIN SHOPPE, INC. & & $\begin{array}{l}\text { POWERWELL PACIFIC } \\
\text { HOLDINGS LIMITED }\end{array}$ & 24. & $\begin{array}{l}\text { EASYKNIT ENTERPRISES } \\
\text { HOLDINGS LIMITED }\end{array}$ \\
\hline 25. & CONN'S, INC. & 26. & $\begin{array}{l}\text { JOS. A. BANK CLOTHIERS, } \\
\text { INC }\end{array}$ & 27. & $\begin{array}{l}\text { BIG } 5 \text { SPORTING GOODS } \\
\text { CORPORATION }\end{array}$ \\
\hline 28. & SHOE CARNIVAL INC & $\begin{array}{l}29 . \\
\text { BRA }\end{array}$ & $\begin{array}{l}\text { MONRO MUFFLER } \\
\text { KE INC }\end{array}$ & 30. & CHINA AUTO LOGISTICS INC \\
\hline 31. & WET SEAL INC & 32. & $\begin{array}{l}\text { AMERICA'S CAR-MART, } \\
\text { INC }\end{array}$ & 33. & $\begin{array}{l}\text { CHINA HELI RESOURCE } \\
\text { RENEWABLE INC }\end{array}$ \\
\hline 34. & FOREFRONT GROUP LIMITED & 35. & LOJAS HERING S.A. & 36. & $\begin{array}{l}\text { SHOPPING CENTERS } \\
\text { PARAGUAY S.A.E. }\end{array}$ \\
\hline 37. & $\begin{array}{l}\text { IMPLEMENTOS Y } \\
\text { MAQUINARIAS AGRICOLAS } \\
\text { S.R.L. - IMAG }\end{array}$ & 38. & $\begin{array}{l}\text { CAVE SHEPHERD \& CO. } \\
\text { LTD. }\end{array}$ & 39. & $\begin{array}{l}\text { STYLAND HOLDINGS } \\
\text { LIMITED }\end{array}$ \\
\hline
\end{tabular}




\begin{tabular}{|c|c|c|c|c|c|}
\hline 40. & $\begin{array}{l}\text { MERCOTEC SOCIEDAD DE } \\
\text { RESPONSABILIDAD } \\
\text { LIMITADA }\end{array}$ & 41. & VICTORY GROUP LIMITED & 42. & $\begin{array}{l}\text { BIG } 5 \text { SPORTING GOODS } \\
\text { CORPORATION }\end{array}$ \\
\hline 43. & $\begin{array}{l}\text { HKC INTERNATIONAL } \\
\text { HOLDINGS LIMITED }\end{array}$ & 44. & $\begin{array}{l}\text { COURTS (BARBADOS) } \\
\text { LTD. }\end{array}$ & 45. & $\begin{array}{l}\text { GRUPO COMERCIAL GOMO, } \\
\text { S.A. DE C.V. }\end{array}$ \\
\hline 46. & $\begin{array}{l}\text { SILVER BASE GROUP } \\
\text { HOLDINGS LTD }\end{array}$ & 47. & UKF (HOLDINGS) LIMITED & 48. & G.A. HOLDINGS LIMITED \\
\hline 49. & TAPE RUVICHA S.A.E.C.A. & 50. & $\begin{array}{l}\text { HARDWARE \& LUMBER } \\
\text { LIMITED }\end{array}$ & 51. & $\begin{array}{l}\text { LUXEY INTERNATIONAL } \\
\text { (HOLDINGS) LIMITED }\end{array}$ \\
\hline 52. & $\begin{array}{l}\text { MILAN STATION HOLDINGS } \\
\text { LIMITED }\end{array}$ & 53. & $\begin{array}{l}\text { AMERICA'S CAR-MART, } \\
\text { INC. }\end{array}$ & & \\
\hline
\end{tabular}

Canada

\begin{tabular}{|l|l|l|}
\hline 1.ROSS STORES INC & 2. COSTCO WHOLESALE CORP & 3. KROGER CO \\
\hline 4. HOME DEPOT INC & 5. TARGET CORP & 6. AMAZON.COM, INC \\
\hline 7. LOWE'S COMPANIES, INC & 8. SYSCO CORP & 9. TJX COMPANIES INC \\
\hline 10. STAPLES INC & 11. KOHLS CORPORATION & 12. GENUINE PARTS CO \\
\hline 13. NORDSTROM INC & 14. CARMAX INC & 15.L BRANDS, INC \\
\hline $\begin{array}{l}\text { 16. FAMILY DOLLAR STORES, INC } \\
\text { 17. LIBERTY INTERACTIVE } \\
\text { CORPORATION }\end{array}$ & 18 WAL-MART STORES, INC. \\
\hline $\begin{array}{l}\text { 19. CORE-MARK HOLDING } \\
\text { 20. REILLY AUTOMOTIVE INC }\end{array}$ & 23. UNITED NATURAL FOODS INC & $\begin{array}{l}\text { 24. SUSSER HOLDINGS } \\
\text { CORPORATION }\end{array}$ \\
\hline 25. BIG LOTS, INC & 26. ANDERSONS INC & 27. ASCENA RETAIL GROUP, INC \\
\hline 28. HARRIS TEETER SUPER & & \\
\hline MARKETS INC & &
\end{tabular}

Brazil

\begin{tabular}{|l|l|l|}
\hline 1. ABERCROMBIE \& FITCH CO & 2. LKQ CORPORATION & 3. CABELA'S INCORPORATED \\
\hline 4. TIFFANY \& CO & 5. INGLES MARKETS INC & 6. MENS WEARHOUSE INC \\
\hline 7. SPARTAN STORES INC & 8. GENESCO INC & $\begin{array}{l}\text { 9. COSMETICS \& FRAGRANCE, } \\
\text { INC }\end{array}$ \\
\hline 10. HHGREGG, INC & & 12. FREDS INC \\
\hline
\end{tabular}

Cayman Islands

\begin{tabular}{|l|l|l|}
\hline $\begin{array}{l}\text { 1. CHOW TAI FOOK JEWELLERY } \\
\text { GROUP LIMITED }\end{array}$ & $\begin{array}{l}\text { BELLE INTERNATIONAL } \\
\text { HOLDINGS LIMITED }\end{array}$ & $\begin{array}{l}\text { 3. } \\
\text { SHINA ZHENGTONG AUTO } \\
\text { LIMITED }\end{array}$ \\
\hline
\end{tabular}




\begin{tabular}{|l|l|l|}
\hline $\begin{array}{l}\text { 4. BAOXIN AUTO GROUP } \\
\text { LIMITED }\end{array}$ & HENGDELI HOLDINGS LIMITED & $\begin{array}{c}\text { 6. } \\
\text { SA SA INTERNATIONAL } \\
\text { HOLDINGS LIMITED }\end{array}$ \\
\hline $\begin{array}{l}\text { 7. GRAND OCEAN RETAIL } \\
\text { GROUP LIMITED }\end{array}$ & $\begin{array}{l}\text { CHINA HARMONY AUTO } \\
\text { HOLDING LIMITED } \\
\text { INTERNATIONAL HOLDINGS } \\
\text { LIMITED }\end{array}$ \\
\hline $\begin{array}{l}\text { 10. MAOYE INTERNATIONAL } \\
\text { HOLDINGS LIMITED }\end{array}$ & \multicolumn{2}{|}{} \\
\hline
\end{tabular}

Thailand

\begin{tabular}{|l|l|ll|}
\hline $\begin{array}{l}\text { 1. PTG ENERGY PUBLIC } \\
\text { COMPANY LIMITED }\end{array}$ & $\begin{array}{l}\text { 2.PTG ENERGY PUBLIC COMPANY } \\
\text { LIMITED }\end{array}$ & $\begin{array}{l}\text { 5. } \\
\text { PTG ENERGY PUBLIC } \\
\text { COMPANY LIMITED }\end{array}$ \\
\hline $\begin{array}{l}\text { PCL } \\
\text { HOME PRODUCT CENTER }\end{array}$ & $\begin{array}{l}\text { S. HOME PRODUCT CENTER PCL } \\
\text { SAHA PATHANAPIBUL PCL }\end{array}$ & $\begin{array}{l}\text { HOME PRODUCT CENTER } \\
\text { PCL }\end{array}$ \\
\hline $\begin{array}{l}\text { 12. SAHA PATHANAPIBUL PCL } \\
\text { SIAM GLOBAL HOUSE PCL }\end{array}$ & 13. SIAM GLOBAL HOUSE PCL & 11. & SAHA PATHANAPIBUL PCL \\
\hline & & & SIAM GLOBAL HOUSE PCL \\
\hline
\end{tabular}

Indonesia

\begin{tabular}{|c|c|c|c|c|}
\hline 1. & $\begin{array}{l}\text { INDOMOBIL SUKSES } \\
\text { INTERNASIONAL TBK }\end{array}$ & & $\begin{array}{l}\text { INDOMOBIL SUKSES } \\
\text { INTERNASIONAL TBK }\end{array}$ & $\begin{array}{l}\text { 3. INDOMOBIL SUKSES } \\
\text { INTERNASIONAL TBK }\end{array}$ \\
\hline 4. & MULTIPOLAR TBK & 5. & MULTIPOLAR TBK & 6. MULTIPOLAR TBK \\
\hline 7. & $\begin{array}{l}\text { MATAHARI PUTRA PRIMA } \\
\text { TBK }\end{array}$ & 8. & MATAHARI PUTRA PRIMA TBK & $\begin{array}{l}\text { 9. MATAHARI PUTRA PRIMA } \\
\text { TBK }\end{array}$ \\
\hline 10. & PT TUNAS RIDEAN TBK & 11. & PT TUNAS RIDEAN TBK & 12. PT TUNAS RIDEAN TBK \\
\hline 13. & $\begin{array}{l}\text { PERDANA BANGUN PUSAKA } \\
\text { TBK }\end{array}$ & & & \\
\hline
\end{tabular}

\section{China}

\begin{tabular}{|c|c|c|c|c|}
\hline 1. & $\begin{array}{l}\text { SUNING COMMERCE GROUP } \\
\text { CO., LTD. }\end{array}$ & 2. & $\begin{array}{l}\text { HUNAN FRIENDSHIP \& } \\
\text { APOLLO COMMERCIAL CO., } \\
\text { LTD. }\end{array}$ & $\begin{array}{l}\text { 3. BEIJING WANGFUJING } \\
\text { DEPARTMENT STORE (GROUP) } \\
\text { CO., LTD. }\end{array}$ \\
\hline 4. & $\begin{array}{l}\text { PANGDA AUTOMOBILE } \\
\text { TRADE COMPANY LIMITED }\end{array}$ & 5. & $\begin{array}{l}\text { SHANGHAI JAHWA UNITED } \\
\text { CO., LTD. }\end{array}$ & $\begin{array}{l}\text { 6. } \text { RAINBOW DEPARTMENT } \\
\text { STORE COMPANY LIMITED }\end{array}$ \\
\hline 7. & $\begin{array}{l}\text { ZHEJIANG MATERIAL } \\
\text { INDUSTRIAL ZHONGDA } \\
\text { YUANTONG GROUP CO., LTD. }\end{array}$ & 8. & $\begin{array}{l}\text { NANJING TEXTILES IMPORT } \\
\text { \& EXPORT CORP., LTD. }\end{array}$ & $\begin{array}{l}\text { 9. JIANGSU HONGTU HIGH } \\
\text { TECHNOLOGY CO., LTD. }\end{array}$ \\
\hline 10. & DASHANG CO., LTD. & 11. & GUANGZHOU FRIENDSHIP & 12. SILVER PLAZA GROUP CO., \\
\hline
\end{tabular}




\begin{tabular}{|c|c|c|c|c|}
\hline & & & GROUP CO., LTD. & LTD. \\
\hline 13. & $\begin{array}{l}\text { CHONGQING DEPARTMENT } \\
\text { STORE CO., LTD. }\end{array}$ & 14. & $\begin{array}{l}\text { WUHAN ZHONGNAN } \\
\text { COMMERCIAL GROUP CO., } \\
\text { LTD. }\end{array}$ & $\begin{array}{l}\text { 15. BEIJING CAPITAL RETAILING } \\
\text { GROUP CO., LTD. }\end{array}$ \\
\hline 16. & $\begin{array}{l}\text { SHANGHAI YUYUAN TOURIST } \\
\text { MART CO., LTD. }\end{array}$ & 17. & $\begin{array}{l}\text { CHANGSHA TONGCHENG } \\
\text { HOLDINGS CO., LTD }\end{array}$ & $\begin{array}{l}\text { 18. LIAONING CHENG DA CO., } \\
\text { LTD. }\end{array}$ \\
\hline 19. & $\begin{array}{l}\text { CHANGCHUN EURASIA } \\
\text { GROUP CO., LTD. }\end{array}$ & 20. & $\begin{array}{l}\text { ANHUI XINHUA MEDIA } \\
\text { COMPANY LIMITED }\end{array}$ & $\begin{array}{l}\text { 21. HEFEI DEPARTMENT STORE } \\
\text { GROUP CO., LTD. }\end{array}$ \\
\hline 22. & $\begin{array}{l}\text { ZHEJIANG ORIENT HOLDINGS } \\
\text { CO., LTD }\end{array}$ & 23. & $\begin{array}{l}\text { YINCHUAN XINHUA } \\
\text { COMMERCIAL (GROUP) CO., } \\
\text { LTD. }\end{array}$ & $\begin{array}{l}\text { 24. SHANGHAI NEW WORLD CO., } \\
\text { LTD. (SNW) }\end{array}$ \\
\hline 25. & $\begin{array}{l}\text { XINJIANG YOUHAO (GROUP) } \\
\text { CO., LTD. }\end{array}$ & 26. & $\begin{array}{l}\text { NANJING CENTRAL } \\
\text { EMPORIUM (GROUP) STOCKS } \\
\text { CO., LTD. }\end{array}$ & $\begin{array}{l}\text { 27. XI'AN KAIYUAN INVESTMENT } \\
\text { GROUP CO., LTD. }\end{array}$ \\
\hline 28. & $\begin{array}{l}\text { WUXI COMMERCIAL } \\
\text { MANSION GRAND ORIENT } \\
\text { CO., LTD. }\end{array}$ & 29. & $\begin{array}{l}\text { GIFORE AGRICULTURAL } \\
\text { MACHINERY CHAIN } \\
\text { COMPANY LIMITED }\end{array}$ & $\begin{array}{l}\text { 30. ZHONGXING SHENYANG } \\
\text { COMMERCIAL BUILDING } \\
\text { GROUP CO., LTD. }\end{array}$ \\
\hline 31. & $\begin{array}{l}\text { JIANGSU HIGH HOPE } \\
\text { CORPORATION }\end{array}$ & 32. & SHANGHAI SHENDA CO., LTD. & $\begin{array}{l}\text { 33. XI'AN MINSHENG GROUP CO., } \\
\text { LTD. }\end{array}$ \\
\hline 34. & $\begin{array}{l}\text { JIANGSU HOLLY } \\
\text { CORPORATION }\end{array}$ & 35. & $\begin{array}{l}\text { HANGZHOU JIEBAI GROUP } \\
\text { CO., LIMITED. }\end{array}$ & $\begin{array}{l}\text { 36. HIT SHOUCHUANG } \\
\text { TECHNOLOGY CO., LTD. }\end{array}$ \\
\hline 37. & $\begin{array}{l}\text { DALIAN FRIENDSHIP (GROUP) } \\
\text { CO., LTD. }\end{array}$ & 38. & $\begin{array}{l}\text { CHENGSHANG GROUP CO., } \\
\text { LTD. }\end{array}$ & $\begin{array}{l}\text { 39. WUHAN HANSHANG GROUP } \\
\text { CO., LTD. }\end{array}$ \\
\hline 40. & $\begin{array}{l}\text { NANJING XINJIEKOU } \\
\text { DEPARTMENT STORE CO., } \\
\text { LTD. }\end{array}$ & 41. & $\begin{array}{l}\text { FUJIAN DONGBAI (GROUP) } \\
\text { CO., LTD }\end{array}$ & $\begin{array}{l}\text { 42. HAINAN ISLAND } \\
\text { CONSTRUCTION CO., LTD. }\end{array}$ \\
\hline 43. & $\begin{array}{l}\text { FUJIAN ZHANGZHOU } \\
\text { DEVELOPMENT CO., LTD. }\end{array}$ & 44. & $\begin{array}{l}\text { HAINING CHINA LEATHER } \\
\text { MARKET COMPANY LIMITED }\end{array}$ & $\begin{array}{l}\text { 45. TIANJIN QUANYE BAZAAR } \\
\text { (GROUP) CO., LTD. }\end{array}$ \\
\hline 46. & $\begin{array}{l}\text { KUNMING SINOBRIGHT } \\
\text { (GROUP) CO., LTD. }\end{array}$ & 47. & $\begin{array}{l}\text { MAOYE LOGISTICS } \\
\text { CORPORATION LIMITED }\end{array}$ & $\begin{array}{l}\text { 48. SANLIAN COMMERCE CO., } \\
\text { LTD. }\end{array}$ \\
\hline 49. & $\begin{array}{l}\text { NANNING DEPARTMENT } \\
\text { STORE CO., LTD. }\end{array}$ & 50. & $\begin{array}{l}\text { SHENYANG COMMERCIAL } \\
\text { CITY CO., LTD. }\end{array}$ & $\begin{array}{l}\text { 51. MINSHENG INVESTMENT } \\
\text { MANAGEMENT COMPANY } \\
\text { LIMITED }\end{array}$ \\
\hline 52. & $\begin{array}{l}\text { SHANGHAI YIMIN } \\
\text { COMMERCIAL GROUP CO., } \\
\text { LTD. }\end{array}$ & 53. & $\begin{array}{l}\text { LIAONING SHIDAI WANHENG } \\
\text { CO., LTD. }\end{array}$ & $\begin{array}{l}\text { 54. SICHUAN DATONG GAS } \\
\text { DEVELOPMENT CO., LTD. }\end{array}$ \\
\hline 55. & BEIJING URBAN-RURAL & 56. & SUNNY LOAN TOP CO., LTD. & 57. HARBIN CHURIN GROUP \\
\hline
\end{tabular}




\begin{tabular}{|c|c|c|c|c|}
\hline & TRADE CENTRE CO., LTD. & & & \\
\hline 58. & $\begin{array}{l}\text { LANZHOU MINBAI } \\
\text { SHAREHOLDING (GROUP) CO., } \\
\text { LTD. }\end{array}$ & & $\begin{array}{l}\text { SHENZHEN TELLUS HOLDING } \\
\text { CO., LTD. }\end{array}$ & 60. JOINTSTOCK CO., LTD. \\
\hline 61. & BAIDA GROUP CO., LTD & 62. & $\begin{array}{l}\text { CHANGCHUN DEPARTMENT } \\
\text { JITUAN STORE COMPANY } \\
\text { LIMITED }\end{array}$ & 63. SHANGHAI JOIN BUY CO., LTD \\
\hline
\end{tabular}

India
\begin{tabular}{|ll|l|l|}
\hline 1. & FUTURE RETAIL LIMITED & 2. LAHOTI OVERSEAS LTD. & 3. YARN SYNDICATE LTD. \\
\hline 4. & SHOPPER'S STOP LIMITED & 5. CRAVATEX LTD. & 6. KEMP \& COMPANY LTD \\
\hline 7. & TRENT LIMITED & 8. ARCHIES LTD. & $\begin{array}{l}\text { 9. ATHARV ENTERPRISES } \\
\text { LIMITED }\end{array}$ \\
\hline 10. & ASIAN STAR CO. LTD. & 11. J.L. MORISON (INDIA) LTD. & $\begin{array}{l}\text { 12. COMPETENT AUTOMOBILES } \\
\text { CO. LTD }\end{array}$ \\
\hline 13. & BRANDHOUSE RETAILS LTD. & $\begin{array}{l}\text { 14. BOMBAY SWADESHI STORES } \\
\text { 15. V-MART RETAIL LIMITED }\end{array}$ & \\
\hline 16. DEVINE IMPEX & LTD. & \multicolumn{1}{|c|}{} \\
\end{tabular}

\begin{tabular}{|c|c|c|}
\hline $\begin{array}{l}\text { 1. AUTOMOTIVE HOLDINGS } \\
\text { GROUP LIMITED }\end{array}$ & 2. JB HI-FI LIMITED & 3. AP EAGERS LIMITED \\
\hline 4. MYER HOLDINGS LIMITED & $\begin{array}{l}\text { 5. HARVEY NORMAN HOLDINGS } \\
\text { LIMITED }\end{array}$ & 6. PACIFIC BRANDS LIMITED \\
\hline 7. FUNTASTIC LIMITED & $\begin{array}{l}\text { 8. SUPER RETAIL GROUP } \\
\text { LIMITED }\end{array}$ & 9. RURALCO HOLDINGS LIMITED \\
\hline $\begin{array}{l}\text { 10.WOTIF.COM HOLDINGS } \\
\text { LIMITED }\end{array}$ & 11. DAVID JONES LIMITED & 12. REJECT SHOP LIMITED (THE) \\
\hline 13.NICK SCALI LIMITED & 14. THORN GROUP LIMITED & $\begin{array}{l}\text { 15. SPECIALTY FASHION GROUP } \\
\text { LIMITED }\end{array}$ \\
\hline 16. NONI B LIMITED & 17. BREVILLE GROUP LIMITED & 18. VITA GROUP LIMITED \\
\hline 19.WEBJET LIMITED & $\begin{array}{l}\text { 20. FANTASTIC HOLDINGS } \\
\text { LIMITED }\end{array}$ & $\begin{array}{l}\text { 21. CASH CONVERTERS } \\
\text { INTERNATIONAL LIMITED }\end{array}$ \\
\hline 22.OROTONGROUP LIMITED & 23. ULTRA SALON INC & \\
\hline
\end{tabular}

Abbreviation:

INC - Incorporation 


\section{Macrothink}

PLC - Public Company Limited

CO LTD - Company Limited

CORP - Corporation

LTD - Limited 